\title{
Michał Sosnowski
}

Uniwersytet Ekonomiczny we Wrocławiu

e-mail: michal.sosnowski@ue.wroc.pl

\section{ROLA I ZNACZENIE PREFERENCJI PODATKOWYCH W PODATKACH LOKALNYCH}

\section{THE ROLE AND IMPORTANCE OF TAX PREFERENCES IN LOCAL TAXES}

DOI: $10.15611 /$ pn.2018.528.19

JEL Classification: H20, H30, H71

Streszczenie: W artykule omówiono problematykę wykorzystywania ulg i zwolnień podatkowych w podatkach lokalnych przez władze samorządowe w ich polityce fiskalnej. Przedstawiono podatki lokalne w polskim systemie podatkowym oraz omówiono istotę ulg i zwolnień podatkowych jako elementu konstrukcji podatków w aspekcie prawnym i ekonomicznym. Badaniami empirycznymi objęto poziom, strukturę i dynamikę ulg i zwolnień podatkowych także w odniesieniu do wpływów z podatków lokalnych w latach 2007-2017. W konkluzji stwierdzono, że ulgi i zwolnienia podatkowe mogą stanowić ważne narzędzie aktywnego oddziaływania na procesy gospodarcze, przy zastrzeżeniu, że ich konstrukcja prawna będzie prosta i pozbawiona licznych, często bardzo trudnych do spełnienia warunków. Natomiast w myśl zasady sprawiedliwego opodatkowania konieczne jest eliminowanie preferencji niespełniających żadnej istotnej i pożądanej funkcji gospodarczej czy społecznej, są efektem działania grup nacisku lub niewłaściwego lobbingu.

Słowa kluczowe: polityka fiskalna, podatek lokalny, ulga podatkowa, samorząd.

Summary: The article discusses the issue of using tax reliefs and exemptions in local taxes by self-governments in their fiscal policy. The local taxes in the polish tax system were presented and then the essence of tax concessions and exemptions as elements of tax structure in the legal and economic aspect was discussed. The empirical research concerned the level, structure and dynamics of tax reliefs and exemptions, also in relation to revenues from local taxes in the years 2007 to 2017. The conclusion is that tax reliefs and exemptions can be important tools for actively influencing economic processes, with the proviso that their legal structure will be simple and deprived of numerous, often very difficult to meet conditions. However, in order to comply with the principle of fair taxation, it is necessary to eliminate those preferences that do not meet any significant and desirable economic or social function, which are the result of pressure groups or inappropriate lobbying.

Keywords: fiscal policy, local tax, tax relief, self-government. 


\section{Wstęp}

Każda władza, tak szczebla centralnego, jak i samorządowego, chcąc osiągać swe cele i prowadzić skuteczną politykę ekonomiczną, w tym podatkową, musi w sposób racjonalny posługiwać się będącym w jej dyspozycji instrumentarium. Dzięki przyjętym regulacjom można m.in. oddziaływać na przedsiębiorców, kształtować strukturę konsumpcji gospodarstw domowych, skłonność do oszczędzania, skalę inwestycji etc. Podatki należą do jednych z najważniejszych narzędzi polityki fiskalnej państwa, jednak dopiero precyzyjnie określona konstrukcja każdego podatku staje się konkretnym instrumentem, za pomocą którego można realizować zamierzone cele społeczno-gospodarcze.

Występujące w polskim systemie podatki, których beneficjentem jest samorząd terytorialny, były wielokrotnie poddawane zmianom, które dotyczyły także jego zasadniczych elementów, jakimi są stawki podatkowe oraz ulgi i zwolnienia. W pewien sposób upraszczając, można stwierdzić, że właśnie te elementy mają kluczowe znaczenia dla poziomu opodatkowania poszczególnych podatników czy ich grup. Dlatego też zmiany w tym zakresie wywierają istotny wpływ na zachowania podatników oraz warunki ich życia i gospodarowania.

Na przestrzeni lat można zauważyć i dokonać oceny pewnych prawidłowości związanych z funkcjonowaniem poszczególnych podatków zasilających budżety gmin, szczególnie w aspekcie poziomu dochodów podatkowych determinujących w zasadniczy sposób wielkość dochodów własnych jednostek samorządu terytorialnego (JST), oraz stosowania preferencji podatkowych wynikających z władztwa podatkowego nadanego przez ustawodawcę lokalnej władzy publicznej.

Próba odpowiedzi na pytanie, jak w samorządowej polityce podatkowej wykorzystywano ulgi i zwolnienia w podatkach lokalnych, stanowi podstawowy cel niniejszego opracowania, które swym zakresem zostało ograniczone do zbadania skali stosowania rzeczonych preferencji podatkowych w Polsce w latach 2007-2017.

Nie podlega dyskusji, że główną funkcją podatków jest pozyskiwanie dochodów dla dobra publicznego, jednak uniwersalny katalog zasad podatkowych nakazuje robić to w sposób sprawiedliwy, ponieważ w opodatkowaniu chodzi de facto o dzielenie ciężarów wolnego społeczeństwa. Tak więc, jeżeli system podatkowy nie spełnia kryterium uczciwości i sprawiedliwości, to żadna z jego innych zalet nie będzie mieć znaczenia.

\section{Podatki lokalne w polskim systemie podatkowym}

Omawiając wpływ podatków na określone sfery życia społeczno-gospodarczego, z uwagi na dość liczną grupę różnorodnych podatków wchodzących w skład danego systemu podatkowego celowe jest dokonanie ich klasyfikacji za pomocą określonych kryteriów. Z reguły najczęściej stosowanymi w nauce o podatkach kryteriami klasyfikacji podatków są: przedmiot opodatkowania, stosunek przedmiotu opodat- 
kowania do źródła podatku oraz podział dochodów podatkowych pomiędzy państwo a samorząd. Właśnie to ostatnie z przywołanych kryteriów stanowi w tej pracy przedmiot zainteresowania i punkt wyjścia do dalszych rozważań. Według niego można wyróżnić: podatki państwowe, podatki samorządowe i podatki wspólne. To kryterium klasyfikacji podatków oparte jest na określeniu, kto jest beneficjentem wpływów podatkowych z poszczególnych podatków, a mówiąc inaczej, na rzecz jakiego podmiotu prawnopublicznego owe wpływy są odprowadzane.

W polskich warunkach przyjmuje się, że podatkami państwowymi są: podatek od towarów i usług (VAT), podatek akcyzowy, podatek od gier, zryczałtowany podatek dochodowy w formie ryczałtu od przychodów ewidencjonowanych oraz od przychodów osób duchownych. Z kolei do grupy podatków samorządowych zalicza się podatek od nieruchomości, podatek rolny, podatek leśny, podatek od środków transportowych, zryczałtowany podatek dochodowy w formie karty podatkowej, podatek od spadków i darowizn i podatek od czynności cywilnoprawnych. Natomiast do podatków wspólnych, stanowiących zarówno dochód państwa, jak i jednostek samorządu terytorialnego (JST), należą podatek dochodowy od osób fizycznych oraz podatek dochodowy od osób prawnych. Udział JST poszczególnych szczebli we wpływach z tych dwóch podatków dochodowych jest zróżnicowany w zależności od tego, czy przysporzenie dochodów dotyczy samorządu województwa, powiatu czy gminy (ew. miasta na prawach powiatu).

Podatki lokalne mają o wiele mniejszy zakres oddziaływania niż podatki państwowe w stymulowaniu rozwoju społeczno-gospodarczego, jednak także i tu ważne jest, jaka będzie ich docelowa konstrukcja prawna.

Karta podatkowa [Ustawa z 20 listopada 1998] jest najprostszą formą opodatkowania i skierowana jest do drobnych przedsiębiorców prowadzących działalność usługową, wytwórczo-usługową, handlową lub gastronomiczną przy maksymalnym zatrudnieniu do 5 pracowników. Jej podstawową zaletą jest to, że nie trzeba prowadzić żadnej ewidencji niezbędnej do obliczenia podatku dochodowego ani też składać comiesięcznych deklaracji podatkowych. Podatnik musi jedynie co miesiąc dokonywać stałych wpłat na konto urzędu skarbowego. Wysokość podatku jest niezależna od rzeczywistych efektów prowadzonej działalności, a kwota podatku jest ustalana przez Naczelnika Urzędu Skarbowego, który wydaje decyzję ustalającą wysokość podatku dochodowego w formie karty podatkowej odrębnie na każdy rok podatkowy ${ }^{1}$. Podstawowym minusem tej formy opodatkowania jest to, że podatek musi być opłacony niezależnie od tego, czy działalność jest dochodowa, czy też przynosi stratę.

Podatkowi od czynności cywilnoprawnych [Ustawa z 9 września 2000] podlega obrót prawny majątkiem. Podmiotami tego podatku, co do zasady, są nabywcy

\footnotetext{
${ }^{1}$ Stawka tego podatku zależy od rodzaju działalności, liczby mieszkańców gminy, na terenie której ma być prowadzona działalność, oraz liczby zatrudnianych pracowników czy też liczby maszyn, stanowisk parkingowych, od liczby godzin pracy w miesiącu, a przy sprzedaży posiłków domowych w mieszkaniach od liczby wydawanych posiłków na dobę.
} 
rzeczy i praw majątkowych. W przypadku umowy spółki - podatnikiem jest spółka, z wyjątkiem spółki cywilnej, gdzie podatnikami są wspólnicy [Litwińczuk (red.) 2017, s. 998 i nast.]. Podstawa opodatkowania i stawki podatku określone są odrębnie dla każdej czynności².

Podatek od nieruchomości oraz podatek od środków transportowych zostały uregulowane ustawą z 12 stycznia 1991 r. o podatkach i opłatach lokalnych [Ustawa z 12 stycznia 1991]. Opodatkowaniu podatkiem od nieruchomości podlegają nieruchomości lub obiekty budowlane, tj. grunty, budynki lub ich części, budowle lub ich części związane z prowadzeniem działalności gospodarczej. Z kolei przedmiotem opodatkowania podatkiem od środków transportowych, a jednocześnie jego podstawą, są samochody ciężarowe, ciągniki siodłowe i balastowe przystosowane do używania łącznie z naczepą lub przyczepą o dopuszczalnej masie całkowitej powyżej 3,5 tony oraz przyczepy i naczepy, które łącznie z pojazdem silnikowym posiadają dopuszczalną masę całkowitą co najmniej 7 ton, oraz autobusy. Wysokość kwotowych stawek obu podatków jest wprawdzie ustalana przez radę gminy w drodze uchwały, jednak nie mogą one być wyższe niż te zapisane w ustawie.

W podatku rolnym [Ustawa z 15 listopada 1984] przedmiotem opodatkowania są grunty sklasyfikowane w ewidencji gruntów i budynków jako użytki rolne lub jako grunty zadrzewione i zakrzewione na użytkach rolnych, z wyjątkiem gruntów zajętych na prowadzenie działalności gospodarczej innej niż działalność rolnicza ${ }^{3}$. Podstawą opodatkowania jest liczba hektarów przeliczeniowych dla gruntów gospodarstw rolnych lub hektarów fizycznych - dla pozostałych użytków rolnych. W przypadku gospodarstw rolnych podatek rolny wynosi równowartość pieniężną 2,5 q żyta za każdy hektar przeliczeniowy, natomiast dla pozostałych użytków rolnych - 5 q żyta za każdy ha przeliczeniowy.

Natomiast podatkowi leśnemu [Ustawa z 30 października 2002] podlegają określone w ustawie lasy, z wyjątkiem lasów zajętych na wykonywanie innej działalności gospodarczej niż działalność leśna. Podstawę opodatkowania podatkiem leśnym stanowi powierzchnia lasu, wyrażona w hektarach, wynikająca z ewidencji gruntów i budynków ${ }^{4}$.

\footnotetext{
${ }^{2}$ Maksymalna procentowa stawka podatku wynosi $2 \%$, a najmniejsza to $0,1 \%$, natomiast stawka kwotowa 19 zł jest stosowana w stosunku do czynności ustanowienia hipoteki na zabezpieczenie wierzytelności o wysokości nieustalonej.

${ }^{3}$ Liczba hektarów przeliczeniowych ustalana jest na podstawie powierzchni, rodzajów i klas użytków rolnych (klasy bonitacyjne) wynikających z ewidencji gruntów i budynków oraz zaliczenia ich do jednego z czterech okręgów podatkowych ustalonych w zależności od warunków ekonomicznych i produkcyjno-klimatycznych. Cena 1q żyta obliczona jest według średniej ceny skupu żyta za z 11 kwartałów poprzedzających kwartał poprzedzający rok podatkowy. Średnią cenę ogłasza corocznie Prezes GUS. Rada gminy jest uprawniona do obniżenia cen skupu przyjmowanych jako podstawa obliczania podatku rolnego na obszarze gminy.

${ }^{4}$ Stawka podatkowa za 1 ha lasu stanowi równowartość pieniężną $0,220 \mathrm{~m}^{3}$ drewna, obliczaną według średniej ceny sprzedaży drewna netto uzyskanej przez nadleśnictwa za pierwsze trzy kwartały roku poprzedzającego rok podatkowy, przy czym rada gminy może obniżyć kwotę stanowiącą średnią
} 
Podatek od spadków i darowizn to podatek bezpośredni płacony od przyrostu majątku [Ustawa z 23 lipca 1983]. Podatkowi od spadków i darowizn podlega nabycie przez osoby fizyczne własności rzeczy znajdujących się na terytorium Polski lub praw majątkowych wykonywanych na terytorium Rzeczypospolitej Polskiej, m.in. tytułem: dziedziczenia, polecenia testamentowego, darowizny, zasiedzenia, nieodpłatnego zniesienia współwłasności, zachowku, praw do wkładu oszczędnościowego na podstawie dyspozycji wkładem na wypadek śmierci. Wysokość podatku ustala się w zależności od grupy podatkowej, do której zaliczony jest nabywca, bądź przedmiotu opodatkowania, stosując skalę podatkową lub stawki procentowe.

\section{Ulgi i zwolnienia podatkowe jako element konstrukcji podatków}

Zgodnie z teorią, zmiennymi elementami (cechami) podatku, różnymi dla poszczególnych podatków, są elementy ich konstrukcji, zwane często elementami techniki podatkowej. Są to: zakres podmiotowy (podmiot) podatku, zakres przedmiotowy (przedmiot) podatku, podstawa opodatkowania, stawki i skale podatkowe oraz ulgi i zwolnienia podatkowe. Niekiedy jako uzupełnienie zagadnienia elementów budowy podatku wymienia się także warunki płatności podatku, rozumiejąc przez to zarówno termin płatności świadczenia podatkowego, jak i sposoby i formy jego zapłaty [Kostecki 1985, s. 201 i nast.]. Wszystkie wymienione elementy konstrukcji podatku składają się na jego prawną instytucję.

Ulgi i zwolnienia podatkowe, stanowiące główny przedmiot badania w niniejszym opracowaniu, zdaniem W. Nykiela jawią się bardziej jako niesamoistny element konstrukcji podatku, gdyż - poza ulgą polegającą na bezpośrednim zmniejszeniu kwoty podatku - nie istnieją w oderwaniu od innych elementów tej konstrukcji, a tym samym są w stosunku do tych elementów wtórne [Nykiel 2003, s. 95]. Wskazuje na to analiza budowy, funkcji oraz charakteru ulg i zwolnień, które pozostają w ścisłej zależności z podstawowymi elementami podatku (podmiot, przedmiot, podstawa, stawki) i będącymi formą redukcji jednego lub kilku spośród tych elementów.

Ulgi i zwolnienia podatkowe stanowią preferencje (przywileje) podatkowe, za które uznać należy każde odbiegające od ogólnie obowiązujących norm prawnopodatkowych regulacje prawne, które dla budżetu państwa lub budżetów samorządów skutkują uszczupleniem ich dochodów, a których zadaniem jest wspieranie realizacji celów ogólnospołecznych. Preferencje takie zmieniają ciężar opodatkowania i przysparzają objętym nimi podatnikom określone korzyści [Wacker 1994, s. 733]. Ulgi i zwolnienia podatkowe to takie udogodnienia dotyczące podatków, które wyłączają

cenę sprzedaży drewna, przyjmowaną jako podstawa obliczania podatku leśnego na obszarze gminy. Średnią cenę sprzedaży drewna ustala się na podstawie komunikatu Prezesa GUS ogłaszanego w Monitorze Polskim w terminie 20 dni po upływie trzeciego kwartału. 
z opodatkowania pewne podmioty lub ograniczają zakres przedmiotowy opodatkowania [Sokołowski 1995, s. 40-43]. W literaturze ekonomicznej są one również określane mianem kredytu podatkowego [Kamerschen i in. 1993, s. 259]. Ponadto zwraca się uwagę, iż stanowią formę wspierania indywidualnej konsumpcji kosztem publicznym, często pełniąc funkcję swoistego remedium na złożoność i wady tkwiące wewnątrz systemu podatkowego, które z przyczyn politycznych i społecznie niepopularnych wprost się nie eliminuje [Głuchowski 2002, s. 19, 20].

Ulgi i zwolnienia podatkowe, ze względu na swój wymierny wpływ na faktyczne, a nie nominalne obciążenia podatkowe, stanowią niezwykle ważki element konstrukcji podatku. Mogą przybierać formę powszechnie obowiązujących rozwiązań systemowych bądź też mogą mieć charakter bardziej indywidualny i być stosowane w sposób uznaniowy (fakultatywny) przez uprawnione do tego organy władzy publicznej. Rodzaj, zakres i charakter stosowanych przez państwo preferencji w poszczególnych podatkach to wyraz realizowanej przezeń polityki gospodarczej i społecznej i odzwierciedlenie przyjętej doktryny ekonomicznej, która określa miejsce państwa w gospodarce i stopień jego oddziaływania na procesy w niej zachodzące. Ulgi i zwolnienia podatkowe traktowane są z reguły jako znaczący instrument aktywnego oddziaływania przez władzę na procesy zachodzące w gospodarce. Ich podstawowym zadaniem jest wspieranie bądź stymulowanie pożądanych zachowań podmiotów gospodarczych czy też zapewnienie ochrony i pomocy socjalnej określonym grupom społecznym w ramach prowadzonej przez państwo polityki społecznej. Można zatem stwierdzić, że znajdują one istotne miejsce w realizacji stymulacyjnej funkcji podatków w gospodarce, gdyż poprzez zastosowanie określonych preferencji następuje dywersyfikacja obciążeń podatkowych, a sam podatek może stanowić stymulantę albo destymulantę dla procesu decyzyjnego w przedsiębiorstwach, dotyczącego kwestii zatrudnienia, wielkości produkcji, modernizacji ciągów technologicznych etc.

Intencjonalną konsekwencją zastosowania $\mathrm{w}$ systemie podatkowym ulg oraz zwolnień w głównej mierze jest redukcja ciężarów podatkowych dla podmiotów, do których preferencje zostają skierowane, celem pobudzenia ich działalności i rozwoju. Jest to działanie pożądane ze względu na to, że każdy ciężar podatkowy w pewnym wymiarze ogranicza wolność podejmowania decyzji ekonomicznych podatników poprzez zmniejszenie zakresu prywatnego zaspokojenia ich potrzeb. W założeniu ulgi i zwolnienia mają sprzyjać realizacji określonych strategii gospodarczych, tak w skali makro, jak i w odniesieniu do regionów, branż czy wręcz selektywnie wybranych rodzajów działalności. Na przykład zastosowanie ulg i zwolnień podatkowych o charakterze prorozwojowym i proinwestycyjnym ma na celu zarówno ożywienie wyselekcjonowanych dziedzin przemysłu, jak też może przyczyniać się do niwelowania dysproporcji w rozwoju poszczególnych regionów kraju, zwłaszcza w sytuacji występowania obszarów znacznie zapóźnionych społecznie, gospodarczo i infrastrukturalnie. W zamierzeniu ulgi i zwolnienia kierowane do małych i średnich przedsiębiorstw (MSP) mają również zmniejszać różnice pomiędzy nimi a dużymi 
podmiotami gospodarczymi, a tym samym poprawić pozycję konkurencyjną MSP i zharmonizować rozwój całej gospodarki. Owa stymulacyjna funkcja preferencji podatkowych może okazać się szczególnie istotna w warunkach globalizacji procesów gospodarczych na świecie, co wymusi wzrost poziomu konkurencyjności krajowych przedsiębiorstw. Co istotne, konkurowanie przestaje mieć tylko wymiar cenowy i taniości wytwarzania produktów, ale przede wszystkim oznacza wysokie zaawansowanie technologiczne i wysoką jakość. $Z$ tego też powodu rozsądnie stosowane przez państwo preferencje w podatkach mogą pomóc spełnić to wyzwanie światowej gospodarki i wykorzystać szansę przez krajowe podmioty gospodarcze.

Mimo zbliżonych docelowych skutków stosowanych ulg oraz zwolnień podatkowych, tj. obniżenia wysokości płaconych podatków ${ }^{5}$, oba instrumenty różnią się w doktrynie podatkowej w sposób istotny [Nykiel 1998, s. 178 i nast.]. Mianowicie ulgi podatkowe polegają na zredukowaniu kwantytatywnych elementów konstrukcji podatku, czyli podstawy opodatkowania bądź stawek podatkowych lub samej kwoty podatku już po dokonaniu jego obliczenia, mając za bazę określoną podstawę opodatkowania przy zastosowaniu adekwatnej stawki podatku. W przypadku ulgi podatkowej intencją ustawodawcy jest tylko obniżenie ciężaru podatkowego, a nie rezygnacja $\mathrm{z}$ opodatkowania jako takiego. $\mathrm{Z}$ kolei zwolnienia podatkowe stanowią rodzaj ograniczenia zakresu kwalitatywnych elementów konstrukcji podatku, czyli jego zakresu podmiotowego i przedmiotowego. Powoduje to całkowite bądź częściowe zawężenie tego zakresu, stanowiąc przez to wprowadzenie do systemu podatkowego wyjątków od ogólnie przyjętego w prawie podatkowym podmiotu opodatkowania (zwolnienia podmiotowe) lub przedmiotu opodatkowania (zwolnienia przedmiotowe), a także obu kategorii jednocześnie (zwolnienia o charakterze mieszanym, podmiotowo-przedmiotowe). W rezultacie podstawa opodatkowania jest o te, w ścisły sposób określone tytuły (kategorie stanów faktycznych bądź prawnych) niższa, wskutek czego także wysokość płaconych podatków jest mniejsza aniżeli byłoby to w sytuacji braku tych zwolnień. Ponadto podmiot objęty zwolnieniem pozostaje nadal podatnikiem, w przeciwnym bowiem razie owo zwolnienie nie mogłoby być w stosunku do niego zastosowane, a zatem musi podlegać obowiązkowi podatkowemu.

\footnotetext{
${ }^{5} \mathrm{~W}$ ujęciu normatywnym, zastosowanym w Ordynacji podatkowej, ulga podatkowa to przewidziane w przepisach prawa podatkowego: zwolnienia, odliczenia, obniżenia, zmniejszenia, skutkujące zmniejszeniem podstawy opodatkowania bądź wysokości podatku, z wyjątkiem obniżenia kwoty podatku należnego o kwotę podatku naliczonego, w rozumieniu przepisów o podatku od towarów i usług, oraz innych odliczeń stanowiących element konstrukcji tego podatku [Ustawa z 29 sierpnia 1997, art. 3 pkt 6]. W definicji tej kładzie się nacisk na konsekwencje zastosowania ulg. W sytuacji braku wymienionych skutków, zwolnienia, odliczenia etc. pozbawione są charakteru ulgi podatkowej. Mimo to ustawodawca w innych ustawach i przepisach podatkowych nie traktuje pojęć ulgi i zwolnienia podatkowego tożsamo. Świadczy o tym choćby treść art. 217 Konstytucji RP [Konstytucja RP 1997; Gomułowicz, Małecki 2011, s. 124; Gajl 1996].
} 
Również znaczny stopień skomplikowania konstrukcji ulg podatkowych odróżnia je od zwolnień, których konstrukcja prawna jest z reguły prostsza, a w konsekwencji bardziej transparentna i nie wymaga określenia bardzo szczegółowego i rozbudowanego katalogu warunków, jakie określony podmiot gospodarczy musi spełnić, by skorzystać z tego rodzaju preferencji, co najczęściej towarzyszy regulacjom dotyczącym ulg podatkowych.

\section{Znaczenie fiskalne ulg i zwolnień podatkowych w podatkach lokalnych}

Analiza kształtowania się poziomu ulg i zwolnien ${ }^{6} \mathrm{w}$ podatkach lokalnych w latach 2007-2017 dotyczy zarówno ich kwoty, jak i struktury i dynamiki oraz udziału tych preferencji w dochodach z podatków lokalnych. Jak zaprezentowano w tab. 1, w ciągu badanej dekady poziom ogółu preferencji podatkowych wzrósł o ponad połowę, a po uwzględnieniu inflacji o $22 \%$, jednak dla poszczególnych podatków było to bardzo zróżnicowane.

W ramach podatku od nieruchomości i podatku leśnego wystąpił wzrost kwot udzielanych ulg i zwolnień (odpowiednio o 53,4 i 82,8\%), natomiast w pozostałych nastąpił spadek, przy czym dla karty podatkowej, podatku od spadków i darowizn oraz podatku od czynności cywilnoprawnych kwoty ulg podatkowych na koniec 2017 r. wyniosły zero lub były dalece marginalne, co wskazuje, że oprócz ulg i zwolnień ustawowych, gminy nie stosowały tego narzędzia redukującego ciężar podatku. Można przypuszczać, iż cel fiskalny, a więc pozyskanie możliwie najwyższych dochodów podatkowych do lokalnych budżetów, był w tym przypadku najważniejszy.

Badając natomiast, jaki był udział zastosowanych preferencji odniesiony do kwot dochodów uzyskanych z poszczególnych podatków, stwierdzono, że na koniec badanego okresu we wszystkich podatkach lokalnych udział ten uległ zmniejszeniu, przy czym największy spadek wystąpił w podatku od nieruchomości, chociaż i tak poziom ulg i zwolnień $\mathrm{w}$ relacji do dochodów $\mathrm{z}$ tego podatku był najwyższy ze wszystkich podatków lokalnych (w $2017 \mathrm{r}$. było to 3,26\%). Jak pokazują dane, polityka zmniejszania kwot ulg i zwolnień podatkowych w dochodach podatkowych była w całym okresie konsekwentna, wskutek czego rzeczony udział w latach 2007-2017 zmniejszył się o niemal 0,1 pkt. proc.

Warto również dokonać analizy danych dotyczących kształtowania się struktury preferencji podatkowych udzielanych podatnikom przez władze lokalne. $Z$ badań wynika, że największy odsetek tych preferencji dotyczy podatku od nieruchomości i stanowi ponad 99\% w 2017 r., tj. o niemal 1 pkt proc. więcej niż w 2007 roku. Drugi w kolejności był podatek od środków transportowych (0,4\% w 2017 r.), a trzeci podatek rolny $(0,19 \%$ w 2017 r.), przy czym należy zauważyć, że zarówno w od-

\footnotetext{
${ }^{6}$ Bez ulg i zwolnień ustawowych.
} 
niesieniu do podatku od środków transportowych, jak i podatku rolnego, w ciągu badanego okresu udziały te spadły.

Tabela 1. Ulgi i zwolnienia podatkowe w podatkach lokalnych w latach 2007-2017

\begin{tabular}{|c|c|c|c|c|c|c|c|c|c|c|c|c|}
\hline $\begin{array}{c}\text { Wyszcze- } \\
\text { gólnie- } \\
\text { nie* }\end{array}$ & 2007 & 2008 & 2009 & 2010 & 2011 & 2012 & 2013 & 2014 & 2015 & 2016 & 2017 & $\begin{array}{c}\text { Zmiana } \\
2007- \\
-2017 \\
(w \%)\end{array}$ \\
\hline & \multicolumn{12}{|c|}{ Ulgi i zwolnienia (tys. zł) } \\
\hline PR & 3318,4 & 5247,4 & 3396,0 & \begin{tabular}{|l|}
2129,6 \\
\end{tabular} & 2059,8 & 3630,5 & 2810,3 & 2704,4 & 3979,7 & 1335,6 & 1346,1 & $-59,44$ \\
\hline $\mathrm{PoN}$ & 464122 & 527269 & 596107 & 631940 & 683091 & 717609 & 779695 & 761030 & 850535 & 711844 & 711794 & 53,36 \\
\hline $\mathrm{PL}$ & 316,9 & 361,9 & 340,3 & 338,7 & 402,2 & 536,9 & 436,7 & 411,0 & 491,6 & 502,6 & 579,2 & 82,77 \\
\hline PŚT & 3606,7 & 3609,8 & 4085,4 & 3011,8 & 4222,8 & 3421,3 & 3467,9 & 2830,0 & 2603,6 & 3893,3 & 2664,8 & $-26,12$ \\
\hline $\mathrm{KP}$ & 21,1 & 7,3 & 10,1 & 2,0 & 2,0 & 5,7 & 2,2 & 0,0 & 0,7 & 0,0 & 0,0 & $-100,00$ \\
\hline PSiD & 89,5 & 142,2 & 151,9 & 161,6 & 78,8 & 131,2 & 17,3 & 113,3 & 114,9 & 7,9 & 1,9 & $-97,88$ \\
\hline PCC & 7,6 & 9,7 & 6,1 & 0,5 & 19,9 & 8,0 & 1,0 & 0,6 & 0,5 & 0,0 & 0,0 & $-100,00$ \\
\hline \multirow[t]{2}{*}{ Ogółem } & 471482 & 536647 & 604097 & 637584 & 689876 & 725343 & 786431 & 767089 & 857726 & 717583 & 716386 & 51,94 \\
\hline & \multicolumn{12}{|c|}{ Udział ulg i zwolnień w dochodach podatkowych (w \%) } \\
\hline PR & 0,36 & 0,43 & 0,27 & 0,22 & 0,19 & 0,23 & 0,17 & 0,16 & 0,25 & 0,09 & 0,09 & $-0,27$ \\
\hline PoN & 3,65 & 3,92 & 4,20 & 4,18 & 4,20 & 4,08 & 4,16 & 3,90 & 4,22 & 3,43 & 3,26 & $-0,39$ \\
\hline PL & 0,20 & 0,21 & 0,19 & 0,20 & 0,21 & 0,24 & 0,19 & 0,20 & 0,21 & 0,17 & 0,20 & $-0,01$ \\
\hline PŚT & 0,44 & 0,44 & 0,49 & 0,35 & 0,48 & 0,37 & 0,37 & 0,29 & 0,26 & 0,37 & 0,24 & $-0,20$ \\
\hline $\mathrm{KP}$ & 0,02 & 0,01 & 0,01 & 0,00 & 0,00 & 0,01 & 0,00 & 0,00 & 0,00 & 0,00 & 0,00 & $-0,02$ \\
\hline PSiD & 0,03 & 0,04 & 0,05 & 0,06 & 0,03 & 0,05 & 0,01 & 0,04 & 0,05 & 0,00 & 0,00 & $-0,03$ \\
\hline PCC & 0,00 & 0,00 & 0,00 & 0,00 & 0,00 & 0,00 & 0,00 & 0,00 & 0,00 & 0,00 & 0,00 & 0,00 \\
\hline \multirow[t]{2}{*}{ Ogółem } & 2,67 & 2,92 & 3,26 & 3,29 & 3,36 & 3,27 & 3,34 & 3,13 & 3,42 & 2,74 & 2,59 & $-0,08$ \\
\hline & \multicolumn{12}{|c|}{ Struktura ulg i zwolnień (w \%) } \\
\hline PR & 0,70 & 0,98 & 0,56 & 0,33 & 0,30 & 0,50 & 0,36 & 0,35 & 0,46 & 0,19 & 0,19 & $-0,52$ \\
\hline PoN & 98,44 & 98,25 & 98,68 & 99,11 & 99,02 & 98,93 & 99,14 & 99,21 & 99,16 & 99,20 & 99,36 & 0,92 \\
\hline $\mathrm{PL}$ & 0,07 & 0,07 & 0,06 & 0,05 & 0,06 & 0,07 & 0,06 & 0,05 & 0,06 & 0,07 & 0,08 & 0,01 \\
\hline PŚT & 0,76 & 0,67 & 0,68 & 0,47 & 0,61 & 0,47 & 0,44 & 0,37 & 0,30 & 0,54 & 0,37 & $-0,39$ \\
\hline $\mathrm{KP}$ & 0,00 & 0,00 & 0,00 & 0,00 & 0,00 & 0,00 & 0,00 & 0,00 & 0,00 & 0,00 & 0,00 & 0,00 \\
\hline PSiD & 0,02 & 0,03 & 0,03 & 0,03 & 0,01 & 0,02 & 0,00 & 0,01 & 0,01 & 0,00 & 0,00 & $-0,02$ \\
\hline PCC & 0,00 & 0,00 & 0,00 & 0,00 & 0,00 & 0,00 & 0,00 & 0,00 & 0,00 & 0,00 & 0,00 & 0,00 \\
\hline \multirow[t]{2}{*}{ Ogółem } & 100 & 100 & 100 & 100 & 100 & 100 & 100 & 100 & 100 & 100 & 100 & 0,00 \\
\hline & \multicolumn{12}{|c|}{ Dynamika zmian poziomu ulg i zwolnień rdr (w \%) } \\
\hline PR & $-22,04$ & 58,13 & $-35,28$ & $-37,29$ & $-3,28$ & 76,26 & $-22,59$ & $-3,77$ & 47,16 & $-66,44$ & 0,79 & - \\
\hline $\mathrm{PoN}$ & 13,07 & 13,61 & 13,06 & 6,01 & 8,09 & 5,05 & 8,65 & $-2,39$ & 11,76 & $-16,31$ & $-0,01$ & - \\
\hline $\mathrm{PL}$ & 5,44 & 14,21 & $-5,99$ & $-0,46$ & 18,74 & 33,49 & $-18,66$ & $-5,89$ & 19,61 & 2,24 & 15,25 & - \\
\hline PŚT & $-4,78$ & 0,09 & 13,18 & $-26,28$ & 40,21 & $-18,98$ & 1,36 & $-18,39$ & $-8,00$ & 49,53 & $-31,55$ & - \\
\hline $\mathrm{KP}$ & $-80,27$ & $-65,24$ & 37,54 & $-80,58$ & 2,45 & 184,25 & $-62,08$ & $-100,0$ & 0,00 & 0,00 & 0,00 & - \\
\hline PSiD & $-57,48$ & 58,97 & 6,81 & 6,35 & $-51,25$ & 66,61 & $-86,85$ & 556,68 & 1,44 & $-93,10$ & $-76,28$ & - \\
\hline PCC & 3902,1 & 27,48 & $-37,14$ & $-92,48$ & 4250,5 & $-59,94$ & $-88,12$ & $-33,67$ & $-15,54$ & $-100,0$ & 0,00 & - \\
\hline Ogółem & 12,49 & 13,82 & 12,57 & 5,54 & 8,20 & 5,14 & 8,42 & $-2,46$ & 11,82 & $-16,34$ & $-0,17$ & - \\
\hline
\end{tabular}

* PR - podatek rolny; PoN - podatek od nieruchomości PL - podatek leśny; PŚT - podatek od środków transportowych; KP - karta podatkowa; PSiD - podatek od spadków i darowizn; PCC - podatek od czynności cywilnoprawnych.

Źródło: opracowanie własne na podstawnie danych Departamentu Finansów Samorządu Terytorialnego Ministerstwa Finansów. 
W latach 2007-2017 dynamika zmian rok do roku w poziomie udzielanych ulg i zwolnień podatkowych w przypadku poszczególnych podatków lokalnych charakteryzowała się sporym zróżnicowaniem. Największe roczne zmiany wystąpiły w ramach podatku od czynności cywilnoprawnych, szczególnie w latach 2007 i 2011, i sięgały kilku tysięcy procent, co bez wątpienia było spowodowane efektem bardzo niskiej bazy roku poprzedniego. Natomiast w przypadku większości podatków lokalnych z roku na rok następował spadek kwot preferencji podatkowych udzielanych podatnikom przez samorząd na mocy władztwa podatkowego.

Najmniejsze zmiany rok do roku dotyczyły podatku od nieruchomości oraz w pewnym stopniu - podatku leśnego i podatku od spadków i darowizn, przy czym w przypadku tych ostatnich, tak było tylko do 2012 roku. Dodać też należy, że w latach 2007-2017 jedynie w podatku od nieruchomości kwoty przyznawanych preferencji podatkowych rosły z roku na rok (z wyjątkiem lat 2014, 2016 i 2017), co może świadczyć o tym, że gminy, chcąc pozyskać inwestycje na swoim obszarze, posługiwały się właśnie tym instrumentem stymulacji podatkowej, czyniąc swoją „małą ojczyznę" bardziej przyjazną podatkowo. Tezę tę potwierdza porównanie kwot zarówno bezwzględnych, jak i względnych i ich zmian w czasie.

Obecnie udzielanie ulg i zwolnień podatkowych, kosztem wpływów do budżetu z tytułu podatku od nieruchomości, jest najpopularniejszą zachętą fiskalną dostępną władzy lokalnej, Ma to w przyszłości przyczynić się do dynamicznego rozwoju gmin, redukcji bezrobocia, a tym samym do wzrostu zamożności ich obywateli, co mogłoby przełożyć się na wyższe wpływy podatkowe do lokalnych budżetów. Jest to swoisty rodzaj inwestycji w przyszłość, bowiem dzisiejsza redukcja danin publicznych ma spowodować ich wzrost w przyszłości poprzez wykorzystanie bodźcowych instrumentów polityki podatkowej.

Trzeba podkreślić, że rzeczą najważniejszą w aspekcie wykorzystywania ulg i zwolnien podatkowych w lokalnej polityce podatkowej realizowanej przez władze samorządowe jest to, aby oddziaływanie systemu podatkowego na gospodarkę (i społeczeństwo) poprzez całokształt różnych preferencji podatkowych było skoordynowane z sygnałami płynącymi z samej gospodarki, a tym samym wzmacniało pozytywne impulsy, zamiast je osłabiać czy zniekształcać [Głuchowski 2002, s. 19, 20]. Kierowanie preferencji do ściśle wybranych dziedzin gospodarki ze swej istoty narusza w pewnym stopniu i zakresie konkurencję rynkową, jednakże określone poprzez konkretną politykę gospodarczą zadania państwa mają tu większe znaczenie, zwłaszcza jeśli zadania te dotyczą realizacji funkcji motywacyjnej podatku, której celem jest wzrost gospodarczy, zwiększenie zatrudnienia, eksportu bądź poprawa efektywności ekonomicznej przedsiębiorców. Dlatego też należy dążyć do tego, by żadne preferencje stosowane $\mathrm{w}$ systemie podatkowym nie powodowały nadmiernego zniekształcania konkurencji, co wymaga od władz stanowiących prawo dochowania należytej staranności w konstruowaniu określonych podatkowych instrumentów oddziaływania na gospodarkę oraz przeprowadzania analiz i symulacji ich zastosowania. 
Każdy podatek jest wtedy prawidłowo skonstruowany i efektywnie wypełnia swoją funkcję fiskalną czy stymulacyjną, jeżeli w przekonaniu podatników jest podatkiem sprawiedliwym. W przeciwnym razie trudno oczekiwać, aby za pomocą takiego podatku skutecznie osiągać cele polityki ekonomicznej państwa niezależnie od szczebla władzy państwowej. Współcześnie zasada sprawiedliwości opodatkowania przede wszystkim sprowadza się do tego, aby dany podatek nie powodował nadmiernego obciążenia świadczeniami na rzecz państwa, zwłaszcza przez osoby żyjące na granicy minimum egzystencji, był równomiernie rozłożony i dostosowany do zdolności płatniczej danego podatnika. Zdaniem J. Harasimowicza system podatkowy musi być oceniany za pomocą dwóch kardynalnych kryteriów. Po pierwsze, poprzez kryterium uwzględniania interesu podatnika, które mówi, iż podatek nie powinien zniechęcać do podejmowania i kontynuowania działalności gospodarczej, a wręcz działać motywacyjnie Po drugie, poprzez kryterium zabezpieczenia interesu państwa, tj. takiego zapewnienia odpowiednich dochodów państwu z podatków, aby mogło ono realizować przyjętą politykę fiskalną [Harasimowicz 1988, s. 126]. W obecnym systemie prawnym społecznej gospodarki rynkowej za podatek sprawiedliwy uważa się podatek zindywidualizowany i zróżnicowany, dostosowany do indywidualnej sytuacji podatnika. Dominuje poziome rozumienie sprawiedliwości, czyli dzielenie społeczeństwa na grupy o konkretnych poziomach majątku lub przychodu.

Zastosowanie preferencji podatkowych przez władzę lokalną, szczególnie jeśli dotyczy to preferencji nieobligatoryjnych, nienarzuconych regulacją ustawową, może być właśnie wyrazem spełnienia, w danej sytuacji i w odniesieniu do określonych podmiotów, zasady sprawiedliwego opodatkowania. Według Z. Fedorowicza pozostawienie pewnej swobody w przepisach podatkowych w zakresie wykorzystywania ulg i zwolnień typu uznaniowego (zindywidualizowanego) nadaje systemowi podatkowemu pewnej elastyczności, która jest niezbędna w przypadkach indywidualnych i o szczególnym charakterze [Fedorowicz 1998, s. 120]. Jest to istotne zwłaszcza na gruncie realizacji społecznych celów polityki państwa, którego zadaniem jest ochrona interesu podatników znajdujących się w trudnych warunkach materialnych na skutek zdarzeń losowych (np. powódź z roku 1997 czy 2010) etc. Jednoznaczne sprecyzowanie i ścisłe zdefiniowanie terminów „ważny interes podatnika” czy „ważny interes publiczny” jest trudne, a wręcz niemożliwe za pomocą stosownych zapisów w prawie, bez czynienia go nazbyt skomplikowanym.

Ulgi i zwolnienia podatkowe mogą stanowić ważne narzędzie aktywnego oddziaływania na procesy gospodarcze, przy zastrzeżeniu, że ich konstrukcja prawna będzie prosta i pozbawiona licznych, często bardzo trudnych do spełnienia warunków, od których zależy możliwość z nich skorzystania. Nazbyt duży rygoryzm w tej materii niwelować może skuteczność takich instrumentów w osiąganiu założonych i przypisanych im celów społeczno-gospodarczych. Także zbyt duża liczba różnych ulg i zwolnień czyni system podatkowy nieprzejrzystym i nienadającym się do osią- 
gania celów fiskalnych i pozafiskalnych. Nie bez znaczenia są tu również koszty nadmiernie rozbudowanego systemu preferencji podatkowych, co stoi w sprzeczności z zasadą taniości opodatkowania.

Warto w tym miejscu zwrócić uwagę na tendencje, jakie wystąpiły pod koniec lat osiemdziesiątych XX w. w polityce podatkowej niektórych państw o wysoko rozwiniętej gospodarce rynkowej. Sprowadzały się one do rezygnacji z różnych ulg i zwolnień podatkowych $\mathrm{w}$ celu maksymalnego rozszerzenia podstawy opodatkowania, co pozwoliło z kolei na obniżenie ogólnego obciążenia podatkowego [Komar 1987]. Działania te podjęto na skutek znacznych kosztów ekonomicznych realizowanej w ten sposób w latach siedemdziesiątych XX w. polityki fiskalnej i względnie niskiej skuteczności podatków jako instrumentu realizacji celów pozafiskalnych w długim okresie [Markowski 1992, s. 92 i nast.].

W rozważaniach dotyczących oceny znaczenia ulg i zwolnień podatkowych w podatkach lokalnych należy rozważyć, czy za pomocą tego instrumentu finansowo-prawnego w dalszym ciągu można efektywnie ukierunkowywać inwestycje i inwestorów na tereny mniej atrakcyjne i zagrożone bezrobociem, zachęcając także kapitał zagraniczny do reinwestowania zysków w Polsce zamiast transferowania ich za granicę. Sama obniżka stawek podatków powoduje, że opłacalność inwestowania w różnych regionach kraju nie zmienia się i nadal bardziej opłaca się inwestować w dużych miastach niż na znacznie mniej atrakcyjnych terenach wiejskich czy obszarach zapóźnionych gospodarczo, które są oddalone od metropolii i charakteryzują się dużym bezrobociem. Dzięki prostym co do konstrukcji i wymagań ulgom podatkowym podmioty gospodarcze mogłyby kierować część zysku na inwestycje zamiast na konsumpcję. Trzeba jednak pamiętać, że poprzez takie preferowanie konkretnych inwestycji danych przedsiębiorstw nie kredytuje się innych inwestycji, być może bardziej opłacalnych z punktu widzenia ekonomii i gospodarki. Ulgi i zwolnienia podatkowe zakłócają w pewnym sensie rynek, tworząc sztuczną opłacalność inwestowania „w siebie”, a tym samym obniżając opłacalność inwestowania w inne gałęzie gospodarki [Sosnowski 2000, s. 59-60]. Dlatego też pojawiające się co pewien czas pomysły, które uzależniają np. obniżkę stawek podatkowych od tworzenia miejsc pracy (a więc stosowania preferencji w podatkach), w kontekście powyższych doświadczeń i skłonności do wypaczania intencji pomysłodawców w procesie legislacyjnym i tworzenia mało precyzyjnych przepisów prawa, należy moim zdaniem oceniać jako kolejną próbę komplikowania systemu podatkowego za cenę niepewnych korzyści społecznych i gospodarczych. Skłania to do konstatacji, że lepszym działaniem w tym obszarze jest stopniowe redukowanie stawek podatkowych i zmiany zasad amortyzacji dla wszystkich przedsiębiorców kosztem rezygnacji z ulg i zwolnień podatkowych.

Bez wątpienia władza publiczna może wspierać rozwój inwestycji realnie efektywnych ekonomicznie, a nie efektywnych dzięki zastosowaniu rozmaitych ulg, co z reguły prowadzi do „niezdrowej” konkurencji. Nie do zaakceptowania jest bowiem 
sytuacja, w której ustanawia się określone preferencje tylko po to, aby wesprzeć nieefektywne podmioty gospodarcze lub sprzyjać ich niegospodarności. Poza tym jest rzeczą oczywistą, że im więcej udziela się ulg i zwolnień jednym podatnikom, tym wyższe obciążenia podatkowe dotyczyć będą musiały pozostałych, co w efekcie może działać na tych drugich antymotywacyjnie i skłaniać ich do ograniczenia rozmiarów działalności gospodarczej czy poziomu inwestycji lub/i konsumpcji - albo też ukrywania źródeł podlegających opodatkowaniu i przechodzenia do szarej strefy gospodarczej. To z kolei może powodować zmniejszenie wpływów podatkowych do budżetu państwa i samorządów.

Badania przeprowadzone m.in. w Stanach Zjednoczonych i Kanadzie przez B.H. Halla i J. van Reenena wykazały, iż 1 dolar przekazany na badania i rozwój $(b+r)$ $\mathrm{w}$ formie ulg podatkowych stymulował wydatek podobnej kwoty na ten sam cel przez samo przedsiębiorstwo [Hall, van Reenen 1999, s. 25-27]. Tylko takie podejście do szeroko pojmowanych preferencji podatkowych może przyczynić się do uproszczenia systemu podatkowego przy jednoczesnym wykorzystaniu tego rodzaju instrumentów stymulującego oddziaływania do poprawy warunków funkcjonowania przedsiębiorców, zwiększenia poziomu ich konkurencyjności i rozwoju całej gospodarki.

\section{Zakończenie}

Kardynalnym zadaniem władzy publicznej jest dbałość o minimalizowanie ujemnego efektu ekonomicznego związanego z płaceniem podatków oraz takie równoważenie danin publicznych, by nie oddziaływały one w sposób negatywny na rozwój działalności gospodarczej. Odnosząc się do lokalnego wymiaru podatkowej polityki państwa, należałoby skonstatować, że niewątpliwie konieczną rzeczą jest podjęcie kroków w kierunku zwiększenia roli władzy lokalnej i jej autonomii w kreowaniu poprzez podatki lokalne własnej polityki podatkowej, szczególnie w aspekcie jej stymulacyjnego oddziaływania na aktywność przedsiębiorców. Wobec malejącego z roku na rok znaczenia karty podatkowej to właśnie pozostałe podatki lokalne, będące w gestii samorządu, stałyby się ważnym elementem tej polityki. Istnienie w ustawach podatkowych ograniczeń co do swobodnego kształtowania poszczególnych elementów konstrukcji podatków, np. w postaci stawek maksymalnych, a zwłaszcza minimalnych, zawęża pole elastycznego manewru w realizacji lokalnej polityki podatkowej, która w coraz większym stopniu powinna koncentrować się na działaniach ogólnych (horyzontalnych), a nie selektywnych, tak aby wspierać w sposób harmonijny rozwój lokalnej gospodarki i społeczności.

Ulgi i zwolnienia podatkowe były, są i będą jednym z istotnych instrumentów lokalnej polityki fiskalnej. Wyeliminowanie ich en bloc z systemu podatkowego byłoby kardynalnym błędem i przejawem braku poczucia realizmu gospodarczego. Najistotniejsze jest tu określenie racjonalnej ekonomicznie konstrukcji takich 
preferencji poprzez nadanie jej cech prostoty i transparentności, co zapewne uczyni je atrakcyjnym dla przedsiębiorców instrumentem polityki podatkowej. Należy zatem pozostawić w systemie podatkowym ulgi i zwolnienia dotyczące realizacji zasady unikania podwójnego opodatkowania, mające charakter zadośćuczynienia lub odszkodowania, związane z realizacją programów pomocowych UE czy wykonywaniem umów offsetowych, celów społecznie użytecznych (np. ochrona środowiska) oraz gospodarczo pożądanych (nieodpłatnie uzyskanie know-how, licencji, patentów czy prace b+r, wdrażanie norm jakościowych oraz zaawansowanych technologii wytwarzania). Z kolei konieczne jest eliminowanie tych, które nie spełniają żadnej istotnej i pożądanej funkcji gospodarczej czy społecznej bądź były wprowadzane jako efekt niewłaściwego lobbingu lub partykularnych interesów grup nacisku.

\section{Literatura}

Fedorowicz Z., 1998, Polityka fiskalna, Wydawnictwo WSB, Poznań.

Gajl N., 1996, Konstytucyjne gwarancje systemu podatkowego, Glosa, nr 9.

Głuchowski J., 2002, Charakterystyka ogólna ulg i zwolnień podatkowych, [w:] Formy zmniejszania wysokości podatków w Polsce, red. J. Głuchowski, PWN, Warszawa.

Gomułowicz A., Małecki J., 2011, Podatki i prawo podatkowe, Wydawnictwo Prawnicze LexisNexis, Warszawa.

Hall B.H., van Reenen J., 1999, How Effective Are Fiscal Incentives for R\&D? A Review of the Evidence, NBER, Working Paper 7098, Cambridge.

Harasimowicz J., 1988, Finanse i prawo finansowe, PWE, Warszawa.

Kamerschen D.R., McKenzie R.B., Nardinelli C., 1993, Ekonomia, Fundacja Gospodarcza NSZZ „Solidarność", Gdańsk.

Komar A., 1987, Reforma amerykańskiego systemu podatkowego i jej znaczeni dla reformy polskiej, Ruch Prawniczy, Ekonomiczny i Socjologiczny, nr 4.

Konstytucja Rzeczypospolitej Polskiej. Dz.U. 1997, nr 78, poz. 483 z późn. zm.

Kostecki A., 1985, Elementy konstrukcji instytucji podatku, [w:] System instytucji prawno-finansowych $P R L$, red. M. Weralski, t. 3, Instytucje budzetowe, Ossolineum, Wrocław.

Litwińczuk H. (red.), 2017, Prawo podatkowe przedsiębiorców, wyd. 8. Wolters Kluwer, Warszawa.

Markowski K., 1992, Rola państwa w gospodarce rynkowej, PWE, Warszawa.

Nykiel W., 1998, Zwolnienia i ulgi podatkowe a konstrukcja podatku (wybrane zagadnienia), Studia $\mathrm{z}$ dziedziny prawa podatkowego, Toruń.

Nykiel W., 2003, Ulgi i zwolnienia podatkowe - podstawowe cechy, [w:] Kierunki reformy polskiego systemu podatkowego, red. A. Pomorska, Wyd. UMCS, Lublin.

Sokołowski J., 1995, Zarzadzanie przez podatki, PWN, Warszawa.

Sosnowski M., 2000, Opodatkowanie osób prawnych jako przesłanka podejmowania przez nie przedsięwzięć gospodarczych, [w:] Fiskalne aspekty polityki gospodarczej państwa i samorząów lokalnych, red. L. Balicki, Prace Naukowe Akademii Ekonomicznej, nr 882, Wyd. Akademii Ekonomicznej we Wrocławiu, Wrocław.

Ustawa z dnia 9 września 2000 r. o podatku od czynności cywilnoprawnych, tekst jednolity, Dz.U. 2017, poz. 1150 . 
Ustawa z 12 stycznia 1991 r. o podatkach i opłatach lokalnych. tekst jednolity, Dz.U. 2018, poz. 1445 z późn. $z m$.

Ustawa z 15 listopada 1984 r. o podatku rolnym, tekst jednolity, Dz.U. 2017, poz. 1892 z późn. zm.

Ustawa z dnia 20 listopada 1998 r. o zryczałtowanym podatku dochodowym od niektórych przychodów osiąganych przez osoby fizyczne, tekst jednolity, Dz.U. 2017, z późn. zm.

Ustawa z dnia 23 lipca 1983 r. o podatku od spadków i darowizn, tekst jednolity, Dz.U. 2018, poz. 644 z późn. zm.

Ustawa z 29 sierpnia 1997 roku - Ordynacja podatkowa, tekst jednolity, Dz.U. 2018, poz. 800 z późn. $\mathrm{zm}$.

Ustawa z 30 października 2002 r. o podatku leśnym, tekst jednolity, Dz.U. 2017, poz. 1821 z późn. zm.

Wacker W.H., 1994, Lexikon der deutschen und internationalen Besteuerung, wyd. 3, Vahlen, München. 